\title{
A Study on the Characteristics of Required Space Composition for Public Libraries in Korea
}

\author{
Hokyun $\mathrm{Lim}^{*^{1}}$ and Hungkwon $\mathrm{Ko}^{2}$ \\ ${ }^{1}$ Assistant Professor, Department of Interior Architecture \& Built Environment, Yonsei University, Korea \\ ${ }^{2}$ Assistant Professor, Department of Interior Architectural Design, Suwon Science College, Korea
}

\begin{abstract}
This study analyzed the current conditions of required spaces and area composition for public libraries, whose meanings and functions shifted due to temporal changes around 2000. Library characteristics were investigated according to size and regional types. Another investigation was performed regarding the common points and differences in area composition through temporal and international comparative analysis. The changes in the required spaces for public libraries were investigated to put current categories of suitable required spaces into the analytical framework. When the area composition was subdivided by size and analyzed, a consistent tendency was found: the larger the gross floor area, the relatively smaller the data usage sector and the larger the public use sector became. The area composition varied by hierarchical roles and regional characteristics. As for differences in the area composition before and after 2000, a greater emphasis was placed on the culture and education sector centered on the lifelong education and community programs of residents since 2000. In addition, special characteristics in area composition for Korean public libraries could be found through a comparative analysis with area compositions from other countries.
\end{abstract}

Keywords: public library; required space; space allocation; space program

\section{Introduction \\ 1.1 Objective and Significance}

Around the 21 st century, the development of multimedia and social changes transformed public libraries into plural and complex places. The value of information had decreased, and the temporal and spatial restrictions on information access had been removed. Information had changed from the concept of possession and reading to that of access and exchange. The concept of a library thus changed from a place for information based on a collection of books to a user-centered space for communication. Information condensation by digital storage made it possible to overcome the restrictions of physical space, enabling the composition of open and convenient reading space, and changed the remaining space into a dynamic one with diverse and complex functions. In other words, public libraries today serve as complex cultural and community centers to improve communication among members of society by allowing the accumulation and exchange of information and culture.

\footnotetext{
*Contact Author: Hokyun Lim, Assistant Professor,

Department of Interior Architecture \& Built Environment,

Yonsei University, 50 Yonsei-ro, Seodaemun-gu,

Seoul, 120-749 Korea

Tel: +82-2-2123-3139 Fax: +82-2-313-3139

E-mail: hglim@yonsei.ac.kr

(Received October 6, 2013 ; accepted February 26, 2014)
}

This study aims to examine the present conditions of public libraries that have changed since 2000 and identify typical characteristics that can be important criteria for space composition among libraries. These typical characteristics will be compared with criteria of other countries to form a set of criteria for space composition suitable for 21 st century public libraries. The results of this study can be used as reference data for size planning during the establishment of public libraries in the future. In addition, this study may offer basic data for various studies concerning the guidelines for public library architecture planning.

\subsection{Range and Methods}

The main target of the analysis in this study was limited to local public libraries that opened after 2000(Division Y). A comparative research study of 10 public libraries that opened before 2000(Division $\mathrm{X})$ was conducted to determine temporal changes. Another comparative research study was conducted among the space criteria for the United States, France, and Spain(Division Z) and 13 specific cases in France(Table 2.) to analyze differences in space composition in public libraries by cultural properties. Korea had 828 public libraries as of 2012, 450 of which were established after 2000. Of these, 140 were investigated in terms of space composition, except for children's areas and large libraries (whose gross floor area is $9,000 \mathrm{~m}^{2}$ or more) that differed from public ones in the aspect of space composition (Table 1.). 
Table 1. Target Facility 1

\begin{tabular}{|c|c|c|c|c|}
\hline Division & Category & $\operatorname{GFA}\left(\mathrm{m}^{2}\right)$ & \multicolumn{2}{|c|}{ Number of cases } \\
\hline $\mathrm{X}$ & $\mathrm{C}$ & $1,500-6,000$ & \multicolumn{2}{|c|}{10} \\
\hline \multirow{9}{*}{ Y } & MS & $470-2,000$ & 25 & \multirow{9}{*}{140} \\
\hline & MM & $2,000-4,000$ & 18 & \\
\hline & ML & $\begin{array}{c}\text { More than } \\
4,000\end{array}$ & 13 & \\
\hline & $\mathrm{CS}$ & $470-2,000$ & 17 & \\
\hline & $\mathrm{CM}$ & $2,000-4,000$ & 16 & \\
\hline & $\mathrm{CL}$ & $\begin{array}{c}\text { More than } \\
4,000\end{array}$ & 16 & \\
\hline & TS & $470-2,000$ & 23 & \\
\hline & TM & $2,000-4,000$ & 12 & \\
\hline & TL & $\begin{array}{c}\text { More than } \\
4,000\end{array}$ & 0 & \\
\hline
\end{tabular}

Note : C (Small and medium size cities), MS (Megapolis regions, Small Section), MM (Megapolis regions, Medium Section), ML (Megapolis regions, Large Section), CS (Small and medium size cities, Small Section), CM (Small and medium size cities, Medium Section), CL (Small and medium size cities, Large Section), TS (Rural areas, Small Section), TM (Rural areas, Medium Section), TL (Rural areas, Large Section)

Table 2. Target Facility 2 (France, site exploration over 3 months in 2007)

\begin{tabular}{l|l|l|l}
\hline Division & Name of library & Open & GFA $\left(\mathrm{m}^{2}\right)$ \\
\hline FS1 & Médiathèque Andre Malraux & 2002 & 1,949 \\
\hline FS2 & Mediatheque Fresnes & 1999 & 2,561 \\
\hline FS3 & Médiathèque de Sélestat & 1997 & 2,816 \\
\hline FM1 & Médiathèque de Roanne & 1997 & 3,331 \\
\hline FM2 & Médiathèque de Vaise-Lyon & 2000 & 3,240 \\
\hline FM3 & Médiathèque d'Antibes & 2006 & 3,980 \\
\hline FM5 & Médiathèque Jacques Baumel & 2005 & 4,378 \\
\hline FL1 & Bédiathèque de l'astrolabe & 2004 & 5,796 \\
\hline FL2 & Médiathèque d'Orléans & 1994 & 6,754 \\
\hline FL3 & Médiathèque Michel-Crépeau & 1998 & 7,265 \\
\hline FL4 & Médiathèque Reims & 2002 & 7,150 \\
\hline FL5 & Médiathèque François Mitterrand & 1996 & 7,881 \\
\hline
\end{tabular}

Note: FS (Médiathèque Small), FM (Médiathèque Medium), FL ( Médiathèque Large)

The methods and stages of this paper were expounded as follows: Chapter 2 presents a literature review and theoretical consideration to establish the categories of required spaces for public libraries. The types of required spaces as defined in prior research and the current conditions of local facilities after 2000 were analyzed to redefine required space categories. Chapter 3 offers space data for the 140 target libraries that opened after 2000 to analyze and determine the space composition ratio.

The libraries were then categorized by region and size to determine differences by types. Type subdivision was made by region in order to identify specific properties and put them into the required space area ratio property for each subsection. In Chapter 4, a comparative analysis is made of the space composition ratio and libraries that opened before 2000 along with a comparison of the space criteria suggested by each of the other countries. An analysis of space composition in French public libraries was conducted to examine cultural and regional differences. The results of this analysis enabled an understanding of physical homogeneity and cultural differences in the space composition of 21 st century public libraries, which could be used as basic data for establishment plans.

\section{Required Spaces for Public Libraries \\ 2.1 Functions and Spaces of Libraries that Opened Before 2000}

It can be said that the required space for public libraries is the space for work organization and functional requirements, which is similar to the meaning of the facility program installed in the building. The Casebook on Architectural Planning (1986) classifies and defines the components of public libraries into book lending on the open shelf system, reference materials, meetings, business, stack rooms, traveling libraries, passageways, and equipment. In space composition, emphasis is placed on the functions of open and closed stack rooms for collection storage, reading and lending, with space for book classification and management and work management.

Lee (1988) divides the functions of the library into four general categories: acquisition and preservation of sufficient data, reference services, book lending, and arrangement works including cataloging and classification. In short, the main functions of the libraries that opened before 2000 were book preservation and reading, which activated the spaces for book stacking and lending, business, and management, making them passive to organized meetings and culture space.

\subsection{Functional Expansion and Changes}

The International Federation of Library Associations (IFLA) classifies required spaces for public libraries into space for collection and library materials, space for readers and users, space for meeting and program functions, business space for library staff, space for other miscellaneous functions, and space for mechanical and support services. The classification of required spaces as suggested by IFLA is the extended concept including space for supporting additional culture and meeting programs based on the material and reading space that are essential to traditional libraries and public service.

The "US Libraries Designed for Users, A $21 \mathrm{st}$ Century Guide", classified required spaces for public libraries into space for major functions and nonassignable space. Inclusion of major function spaces indicated changes in the main functions of libraries, including a collection space to store materials for public use, a people space to read and use computers, a meeting space for programs, tutorials, or group study, and a staff area for public service or staff support services. Non-assignable space includes entrances and vestibules, restrooms, stairs, elevators, hallways, heating, ventilating, and air conditioning equipment, 
maintenance equipment, deliveries, and general storage.

France classifies required spaces for public libraries into Fonction Accueil, Fonction Communication Adultes, Fonction Communication Jeunesse, and Services Interieurs. Fonction Accueil is composed of the circulation desk, information desk, conference, exhibition and multimedia rooms, and children's activity room. Fonction Communication Adultes contains open-stack material space, serials, reading seats, and copy machines.

Spain classifies spaces into reception/promotion area, general area, children's area, and non-public area. The first category of the reception/promotion area contains such supporting spaces as multipurpose space, education space, and a café. The second category of the general area is composed of material space and multimedia, newspaper, and magazine space. There is a separate space for the children's area, and the nonpublic area contains such work management areas as business space and warehouse. This trend gives a new understanding of the importance of cultural space and digital data space in the direction of required spaces for 21 st century public libraries.

The "Manual of Public Library Establishment and Management" (Korea, 2010) classified library spaces into a lending and returning area, a reading, learning, and study area, a reference and information service area, a book preservation area, a convenience area for disabled people, the elderly people, and pregnant women, an exhibition and meeting area, a convenience area for users, an area for young and older children, and a staff area for business and rest. Since the 2000s, the functions of public libraries have been changed into a subdivision of digital data rooms and sectors for exhibition, meeting, rest, and convenience space in addition to the functions of collection preservation and book reading.

Since the 2000 s, the changes in the nature of public libraries have necessitated other areas aside from the space for data usage as their main function, rendering them diversified. Thus, the space inside a public library can be classified by functions consisting of four categories-information storage and access, book preservation and management, culture and information exchange, and rest and communities. These are-further categorized into the data usage sector, the culture and education sector, the work management sector, the public use sector, and the miscellaneous sector. However, there is much variation in the size of the machinery and mechanical room in the miscellaneous sector by the application system and in the size of underground parking space based on regional characteristics (megapolis regions, small and medium size cities, rural areas). On this basis, the categories of functions and required spaces for public libraries can be summarized as in Table 3 .

\section{Analysis of Area Ratio Characteristics for Each Required Space}

3.1 Current Conditions of Area Composition Ratio for Required Spaces

The areas of 140 public libraries established after 2000 were classified into the data usage sector, the culture and education sector, the work management sector, and the public use sector to analyze the ratio for each sector and estimate the detailed area. The other sector, which showed significant deviation in the regional and architectural characteristics of libraries, was separately estimated from the area for public libraries. The percentage of area for each sector was as shown in Table 3. While it can be said that the percentage of area in Table 3. was a useful standard as a reference to estimate the size of public libraries, public libraries could have the percentage of area for each space changed by regional characteristics and hierarchical roles (central or branch library) since they had different roles and methods of operation based on regional characteristics, even if they were identical in size.

Table 3. Required Space and Area Ratio for Public Libraries

\begin{tabular}{|c|c|c|c|c|}
\hline & Sector & Required space & Percen & ge (\%) \\
\hline \multirow{9}{*}{ DU } & \multirow{4}{*}{$\begin{array}{l}\text { General } \\
\text { Collection }\end{array}$} & General & \multirow{4}{*}{19.0} & \multirow{9}{*}{35.9} \\
\hline & & Periodicals & & \\
\hline & & Disabled & & \\
\hline & & Rare/Local & & \\
\hline & $\begin{array}{l}\text { Digital } \\
\text { Collection }\end{array}$ & Multimedia & 5.7 & \\
\hline & \multirow{4}{*}{$\begin{array}{l}\text { Children's } \\
\text { Collection }\end{array}$} & Children & \multirow{4}{*}{11.2} & \\
\hline & & Early Childhood & & \\
\hline & & Storytelling & & \\
\hline & & Cultural Program & & \\
\hline \multirow{4}{*}{$\mathrm{CE}$} & \multicolumn{2}{|c|}{ Culture Education } & 5.2 & \multirow{4}{*}{19.4} \\
\hline & \multirow{2}{*}{\multicolumn{2}{|c|}{$\begin{array}{c}\text { Multipurpose } \\
\text { Exhibition }\end{array}$}} & 5.5 & \\
\hline & \multirow{2}{*}{\multicolumn{2}{|c|}{$\begin{array}{l}\text { Exhibition } \\
\text { Study Room }\end{array}$}} & 1.7 & \\
\hline & & & 7.0 & \\
\hline \multirow{9}{*}{ WM } & \multirow{2}{*}{ Office } & Director/ Work & 3.9 & \multirow{9}{*}{11.3} \\
\hline & & Document storage & 0.2 & \\
\hline & \multirow{5}{*}{$\begin{array}{c}\text { Work } \\
\text { supporting }\end{array}$} & Information Desk & 0.6 & \\
\hline & & Meeting & 0.3 & \\
\hline & & $\begin{array}{l}\text { Staff resting room, } \\
\text { locker room }\end{array}$ & 0.2 & \\
\hline & & Volunteer & 0.1 & \\
\hline & & Server and Networks & 0.9 & \\
\hline & \multirow[t]{2}{*}{ Book Storage } & $\begin{array}{l}\text { Acquisition and } \\
\text { Labeling }\end{array}$ & 1.1 & \\
\hline & & Book Storage & 4.0 & \\
\hline \multirow{3}{*}{ PU } & \multicolumn{2}{|c|}{ Hall, ELEV, Stair, Restroom, etc. } & 28.7 & \multirow{3}{*}{33.4} \\
\hline & \multirow{2}{*}{ Lounge } & Book Café & 2.7 & \\
\hline & & Lounge & 2.0 & \\
\hline \multicolumn{3}{|c|}{ Total } & \multicolumn{2}{|c|}{100.0} \\
\hline \multirow{2}{*}{ Etc. } & & Techanical & 9.0 & \multirow{2}{*}{17.8} \\
\hline & Bas & ment Parking & 8.8 & \\
\hline
\end{tabular}

Note : DU (Data Usage), CE (Culture \& Education), WM (Work Management), PU (Public Use) 


\subsection{Characteristics by Size Classification}

Since public libraries have different functions and roles according to regional characteristics and size, they also have different percentages of area for each sector. The standards for facility classification in the Korean Library Act set the minimum area at $264 \mathrm{~m}^{2}$ according to the target population for service and divided the area into $660 \mathrm{~m}^{2}, 990 \mathrm{~m}^{2}, 1650 \mathrm{~m}^{2}, 3300 \mathrm{~m}^{2}$, and $4950 \mathrm{~m}^{2}$, or more. Lee (2009) classified the size of public libraries into three sections $-264 \mathrm{~m}^{2}$ to $1,650 \mathrm{~m}^{2}, 1,650 \mathrm{~m}^{2}$ to $4,950 \mathrm{~m}^{2}$, and $4,950 \mathrm{~m}^{2}$ or more - with reference to the classification standards in the Korean Library Act. He contended that the percentage of area was differently organized among sectors. The present study classified library size into three sections $-2,000 \mathrm{~m}^{2}$ or less (S: Small Section), 2,000 $\mathrm{m}^{2}$ to $4,000 \mathrm{~m}^{2}$ (M: Medium Section), and $4,000 \mathrm{~m}^{2}$ or more (L: Large Section)on the basis of the mean area of 140 target libraries, in consideration of the classification standards in prior research and the changing roles of libraries. The number of libraries for each section is as shown in Table 1 . However, the French public library classification standards showed an increase by 1.5 times compared with the size of public libraries in consideration of the GDP and population of Korea and France (Fig.1.). Furthermore, the standard categorized libraries into three sections based on size: $3,000 \mathrm{~m}^{2}$ or less (S: Small Section), $3,000 \mathrm{~m}^{2}$ to $6,000 \mathrm{~m}^{2}$ (M: Medium Section), and $6,000 \mathrm{~m}^{2}$ or more (L: Large Section).

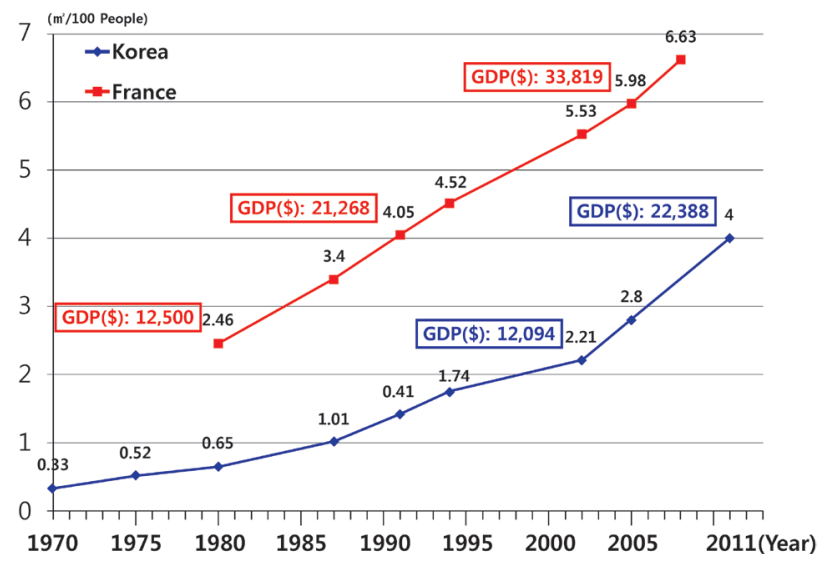

Fig.1. Comparison of Facility Size between Korean and French Public Libraries

The miscellaneous sector (mechanical room, electrical room, underground parking, etc.) was excluded from the percentage of area for libraries since it showed great deviation by regional characteristics and was considered irrelevant to describe certain principles. Certain changes were observed when 140 public libraries were divided into three sections and analyzed as shown in Table 4. As the gross floor area of libraries increased, the data usage sector decreased and the public use sector increased. The L. Section was largely the central building, and the work management sector increased from the S. Section to the L. Section as GFA increased with the increase in business space and stack room for preservation.

Table 4. Size Classification and Percentage of Area (based on 140 libraries, Unit: \%)

\begin{tabular}{c|c|c|c|c|c}
\hline $\begin{array}{c}\text { Size } \\
\text { category }\end{array}$ & $\begin{array}{c}\text { Number of } \\
\text { cases }\end{array}$ & DU & CE & WM & PU \\
\hline S. Section & 65 & 38.2 & 20.3 & 9.5 & 32.0 \\
\hline M. Section & 46 & 34.7 & 20.6 & 11.2 & 33.4 \\
\hline L. Section & 29 & 34.6 & 18.4 & 12.5 & 34.6 \\
\hline
\end{tabular}

The public use sector of the L. Section shown in Fig.2. increased as the data usage sector decreased. However, the management/culture sector of the M. Section shown in Fig.3. decreased as the public use sector increased the L. Section. In contrast, the S. Section had the data sector and the culture sector correlatively changed in Fig.4., while the public use sector changed less compared with the other sizes.

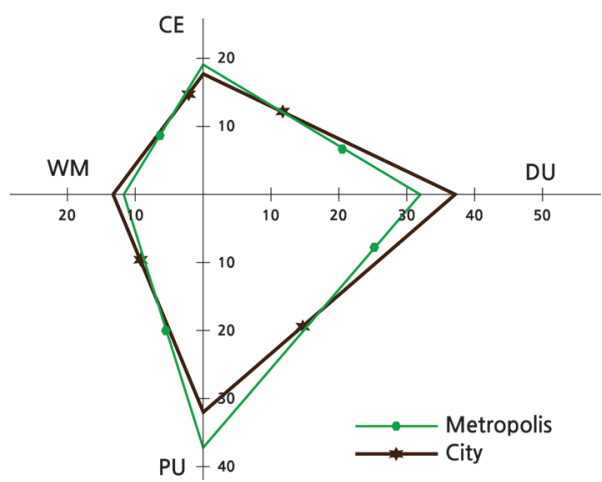

Fig.2. Percentage of Area of the L. Section

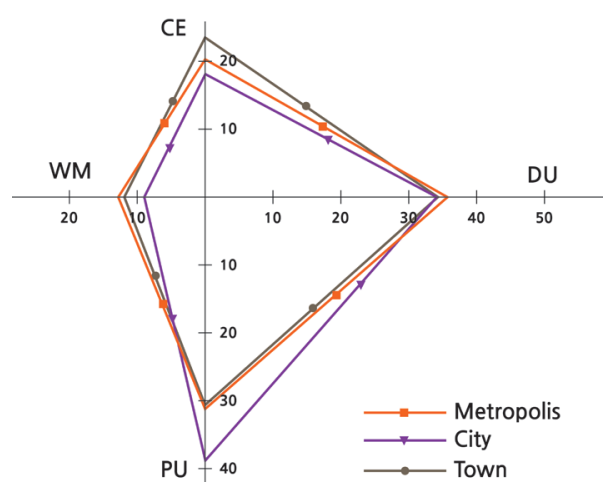

Fig.3. Percentage of Area of the M. Section

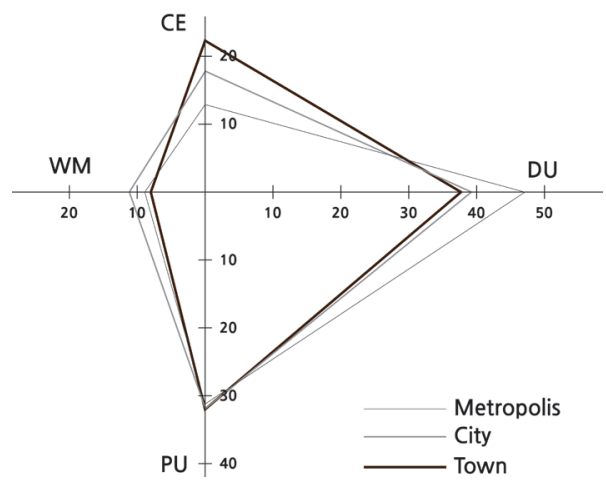

Fig.4. Percentage of Area of the S. Section 


\subsection{Characteristics by Regional Classification}

Public libraries today vary in the size and percentage of area for each sector according to the size of the population and population characteristics in their regions. Their roles differ since the regions adjacent to the libraries vary in population density and population characteristics even if they are identical in size. In contrast, libraries with the same roles can vary in size according to regional characteristics. Thus, the criteria for classifying regional characteristics to build public libraries were categorized into three stages on the basis of population size and population density: megapolis regions (M), small and medium size cities (City), and rural areas (Town).

Table 5. Regional Classification and Area Percentage (based on 140 libraries, Unit: \%)

\begin{tabular}{c|c|c|c|c|c}
\hline $\begin{array}{c}\text { Regional } \\
\text { category }\end{array}$ & $\begin{array}{c}\text { Number of } \\
\text { cases }\end{array}$ & DU & CE & WM & PU \\
\hline Metropolis & 56 & 35.2 & 20.0 & 11.3 & 33.5 \\
\hline City & 49 & 36.8 & 17.9 & 11.2 & 34.2 \\
\hline Town & 35 & 36.0 & 22.9 & 9.9 & 31.2 \\
\hline
\end{tabular}

Certain changes were observed when the percentage of area for each sector in 140 public libraries was regionally divided and analyzed.

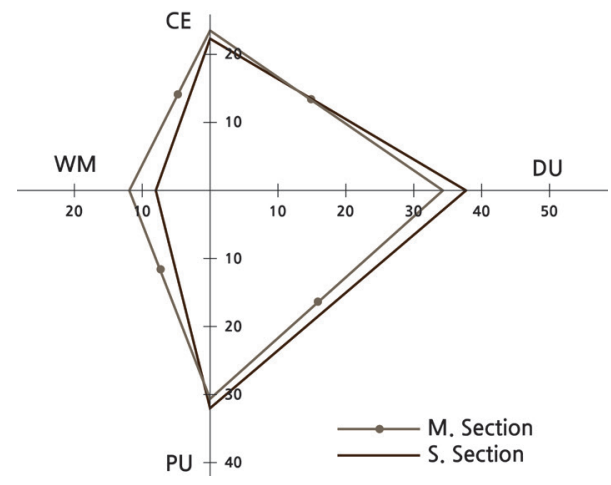

Fig.5. Percentage of Area of Town

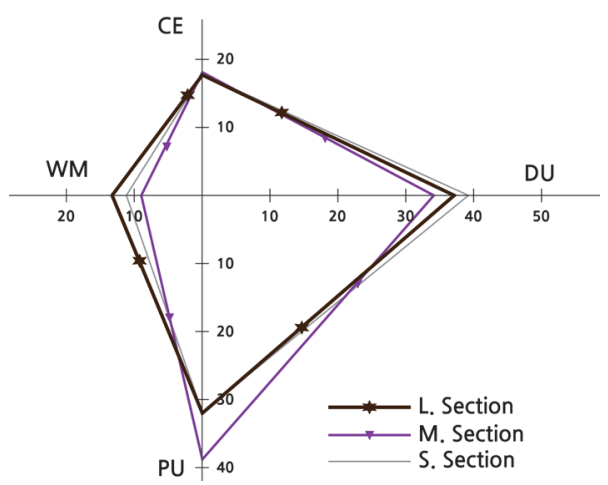

Fig.6. Percentage of Area of City

Town had the highest area percentage for the culture and education sector in Fig.5. This was because public libraries offered lifelong education and functions of local communities as demanded by the aging society in Town with fewer culture facilities compared with other regions. City libraries had a similar percentage of area for the culture and education sector regardless of the size of the libraries. This category had the area of the data usage/management sector and that of the public use sector correlatively changed in Fig.6.

Metropolis had the area of the public use sector and that of the data usage sector correlatively changed to medium and large size but had public libraries of the S. Section characterized by the area percentage based on hierarchical roles, as in Fig.7.

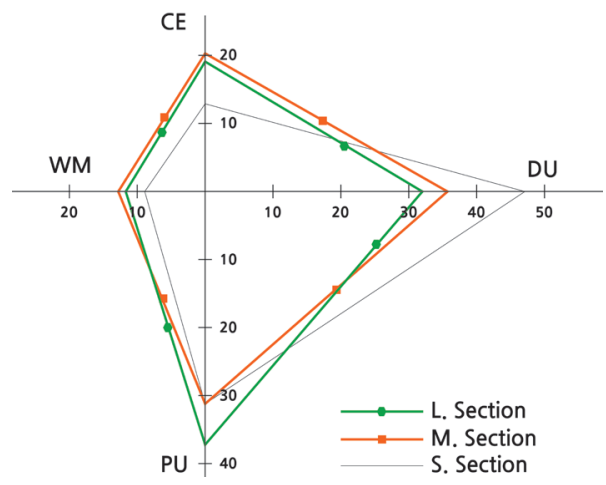

Fig.7. Percentage of Area of Metropolis

\subsection{Characteristics by Region and Size}

One hundred and forty libraries were classified, as shown in Table 6., to analyze the changes in the percentage of area. However, there was no case of TL, and the regional characteristics were identified for the percentage of an area. The S. Section was high in the data usage sector for each region. This was because while the data usage sector for MS and CS had a high percentage of children's data, TS had a higher percentage of general data than children's data. This was the phenomenon formed by the population ratio and correlation for each age group in each region. MS had the data usage sector reinforced and the work management and culture and education sectors reduced; ML had the data usage sector relatively reduced and the public use sector extended. This was because ML had convenience facilities for users that were shifted to community facilities to accommodate complex functions. CM had an average-sized data usage sector, but had a larger culture and education sector and a reduced work management sector due to an increased learning room in the S. Section.

\section{Analysis of Area Composition Ratio 4.1 Comparative Analysis by Time}

Small and medium size cities went through great changes in the area composition ratio for public libraries around the year 2000. Closed stack rooms connected to the circulation room formed $9 \%$ of the data usage sector in public libraries before 2000 compared with the current open shelf system. The study room, which composed $18.1 \%$ of the sector before 2000 and $7 \%$ after 2000 and connected to the data reading sector, was an area for studying rather than for reading data. The area percentage of digital 
Table 6. Percentage of Area by Region and Size (Unit: \%)

\begin{tabular}{|c|c|c|c|c|c|}
\hline \multirow{2}{*}{\multicolumn{2}{|c|}{ Division }} & \multirow{3}{*}{$\begin{array}{c}\text { Detailed space } \\
\text { General Collection }\end{array}$} & \multicolumn{3}{|c|}{ Section } \\
\hline & & & $\mathrm{S}$ & $\mathrm{M}$ & $\mathrm{L}$ \\
\hline \multirow{16}{*}{ M } & \multirow{4}{*}{ DU } & & 18.8 & 19.3 & 17.5 \\
\hline & & Multimedia & 6.1 & 5.5 & 6.8 \\
\hline & & Children's Collection & 12.9 & 10.9 & 7.8 \\
\hline & & Subtotal & 37.8 & 35.7 & 32.0 \\
\hline & \multirow{5}{*}{$\mathrm{CE}$} & Culture Education & 5.5 & 3.2 & 5.3 \\
\hline & & Multipurpose & 6.0 & 6.9 & 4.7 \\
\hline & & Exhibition & 2.1 & 1.8 & 0.8 \\
\hline & & Study Room & 7.1 & 8.4 & 8.3 \\
\hline & & Subtotal & 20.7 & 20.3 & 19.1 \\
\hline & \multirow{4}{*}{ WM } & Office & 3.4 & 3.6 & 4.2 \\
\hline & & Work Supporting & 1.9 & 4.5 & 2.5 \\
\hline & & Book Storage & 4.0 & 4.7 & 5.0 \\
\hline & & Subtotal & 9.3 & 12.8 & 11.7 \\
\hline & \multirow{3}{*}{ PU } & Hall, ELEV, Stair, etc. & 26.2 & 25.4 & 30.4 \\
\hline & & $\begin{array}{l}\text { Lounge } \\
\end{array}$ & 6.0 & 5.8 & 6.8 \\
\hline & & Subtotal & 32.2 & 31.2 & 37.2 \\
\hline \multirow{16}{*}{$\mathrm{C}$} & \multirow{4}{*}{ DU } & General Collection & 17.9 & 18.2 & 20.0 \\
\hline & & Multimedia & 5.6 & 5.3 & 5.4 \\
\hline & & Children's Collection & 15.7 & 10.5 & 11.7 \\
\hline & & Subtotal & 39.2 & 34.1 & 37.1 \\
\hline & \multirow{5}{*}{$\mathrm{CE}$} & Culture Education & 5.3 & 5.3 & 4.9 \\
\hline & & Multipurpose & 5.4 & 3.8 & 6.1 \\
\hline & & Exhibition & 2.4 & 1.1 & 2.1 \\
\hline & & Study Room & 4.7 & 7.9 & 4.6 \\
\hline & & Subtotal & 17.8 & 18.1 & 17.7 \\
\hline & \multirow{4}{*}{ WM } & Office & 3.8 & 3.3 & 3.6 \\
\hline & & Work Supporting & 2.7 & 1.8 & 2.4 \\
\hline & & Book Storage & 4.7 & 3.9 & 7.2 \\
\hline & & Subtotal & 11.2 & 9.0 & 13.2 \\
\hline & \multirow{3}{*}{ PU } & Hall, ELEV, Stair, etc. & 25.5 & 28.3 & 24.9 \\
\hline & & Lounge & 6.4 & 10.5 & 7.1 \\
\hline & & Subtotal & 31.9 & 38.8 & 32.0 \\
\hline \multirow{16}{*}{$\mathrm{T}$} & \multirow{4}{*}{ DU } & General Collection & 21.6 & 17.7 & - \\
\hline & & Multimedia & 5.1 & 4.5 & - \\
\hline & & Children's Collection & 10.9 & 12.2 & - \\
\hline & & Subtotal & 37.7 & 34.3 & \\
\hline & \multirow{5}{*}{$\mathrm{CE}$} & Culture Education & 5.1 & 5.6 & - \\
\hline & & Multipurpose & 6.2 & 8.7 & - \\
\hline & & Exhibition & 2.2 & 1.6 & - \\
\hline & & Study Room & 8.8 & 7.6 & - \\
\hline & & Subtotal & 22.3 & 23.5 & \\
\hline & \multirow{4}{*}{ WM } & Office & 4.3 & 3.5 & - \\
\hline & & Work Supporting & 1.7 & 1.5 & - \\
\hline & & Book Storage & 2.0 & 6.9 & - \\
\hline & & Subtotal & 8.0 & 11.9 & \\
\hline & \multirow{3}{*}{ PU } & Hall, ELEV, Stair, etc. & 27.6 & 25.6 & - \\
\hline & & Lounge & 4.4 & 4.7 & - \\
\hline & & Subtotal & 32.0 & 30.3 & \\
\hline
\end{tabular}

Note: M: Megapolis regions, C: Small and medium size cities, T: Rural areas

data in the data usage sector increased to $5.7 \%$ since 2000. While the culture and education sector mainly consisted of the audio-visual room (5.5\%) before 2000, its area percentage doubled to include the audio-visual room, exhibition room, and cultural room, with the demand for lifelong education increasing since 2000.
In contrast, there was no significant change in the area composition ratio for the work management and public use sectors.

This increase in the area percentage of open shelf systems, digital data, and culture and education rooms was the principal change in public libraries. In other words, public libraries that had been giving priority to book preservation and management before 2000 had diversified since 2000 . They altered to serve as cultural centers and local community centers for lifelong education in addition to the function of preserving books and promoting reading.

Table 7. Comparison of Area Percentage of Public Libraries Before and After 2000 (Unit: \%)

\begin{tabular}{c|c|c|c|c|c|c}
\hline \multirow{2}{*}{$\begin{array}{c}\text { Division } \\
(2000)\end{array}$} & \multicolumn{2}{|c|}{ DU } & \multicolumn{2}{|c|}{ CE } & \multirow{2}{*}{ WM } & \multirow{2}{*}{ PU } \\
\cline { 2 - 5 } & 1 & $(2)$ & $(3)$ & $(4)$ & & \\
\hline Before & 32.8 & 0.5 & 5.5 & 18.1 & 10.6 & 32.4 \\
\hline After & 30.1 & 5.7 & 11.1 & 7.0 & 11.3 & 33.5 \\
\hline
\end{tabular}

Note, (1) Adult/Children, (2) Digital, (3) Lecture Room, (4) Study Room

\subsection{Comparative Analysis by Countries}

Table 8. shows the comparison of the area percentage criteria for public libraries as suggested by the "US Libraries Designed for Users", "French Bibliotheques Dans La Cite", and "Spanish Library Architecture".

Table 8. Area Percentage of Four Countries (Unit: \%)

\begin{tabular}{c|c|c|c|c}
\hline Division & DU & CE & WM & PU \\
\hline USA & 63.8 & 7.5 & 11.3 & 17.4 \\
\hline SPAIN & 56.6 & 17.3 & 8.8 & 17.3 \\
\hline FRANCE & 54.4 & 14.2 & 12.5 & 18.9 \\
\hline KOREA & 35.8 & 19.4 & 11.3 & 33.5 \\
\hline
\end{tabular}

The three countries showed a $22.5 \%$ higher area percentage, on average, for the data usage sector, but approximately a $16 \%$ lower percentage for the public use sector than Korea. In other words, they were identical in that the data usage sector was correlated with the public use sector, but in opposite ways. Overseas cases showed integrated operation of book lending and returning work at the main entrance to create an open space for all users (Fig.8.). However, Korea had book reading areas with lots of public use space for the user circulation flow line. This was because of differences in the manner of operating public libraries (Fig.9.).

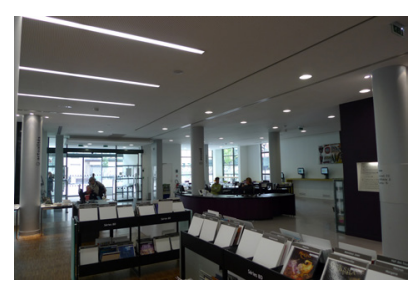

Fig.8. Main Ent.(France)

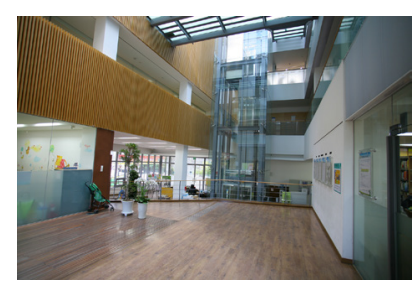

Fig.9. Main Ent.(Korea)
Korea showed a higher percentage of area for the culture and education sector. However, except the percentage of study room $(7 \%)$, the culture and 
education sector of Korean libraries is higher than that of the libraries of the other three countries. The United States, which had the lowest level of the culture and education sector, has public libraries mainly composed of traditional book collection, since the country actively operated learning centers, which eliminate some of the need for culture and education functions.

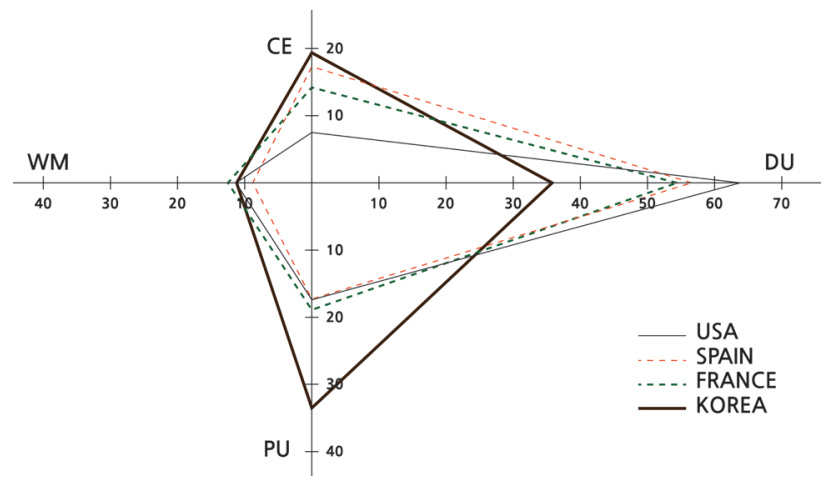

Fig.10. Space Ratios for 4 Countries

When French public libraries were divided into three sections and analyzed, a larger GFA of libraries led to the change in the public use and management sectors based on regional characteristics and hierarchical roles.

Table 9. Size Classification and Area Percentage (based on 13 French libraries, Unit: \%)

\begin{tabular}{c|c|c|c|c|c}
\hline Division & $\begin{array}{c}\text { Number of } \\
\text { Cases }\end{array}$ & DU & CE & WM & PU \\
\hline FS & 3 & 57.3 & 7.9 & 19.5 & 15.3 \\
\hline FM & 5 & 48.6 & 7.4 & 20.1 & 23.9 \\
\hline FL & 5 & 40.8 & 5.8 & 29.5 & 24.0 \\
\hline
\end{tabular}

The S. Section in Fig.2. shows limitations in the number of cases but no change in the area percentage. In contrast, the percentage of area for the work management sector and that for the data usage and public use sectors were correlatively changed by stack rooms for preservation in the M. Section and L. Section. There was almost no change in the percentage of area for the culture and education sector by size.

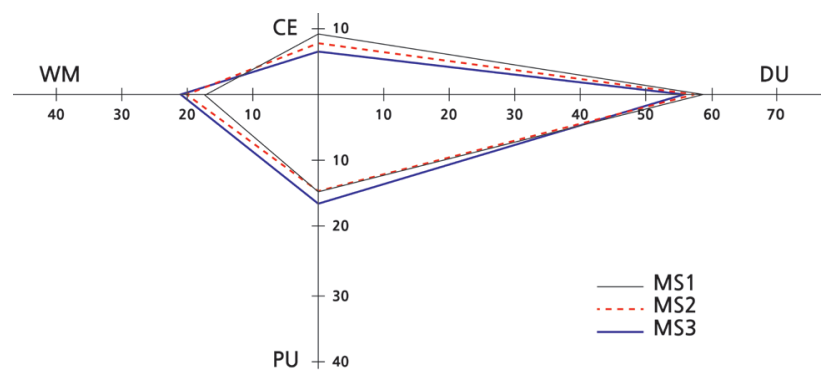

Fig.11. Percentage of Area for the France S. Section

When the percentage of area in the size criteria for public libraries in three other countries and 13 French cases was compared with that for 140 Korean public libraries, there were characteristics of the percentage of area reflecting specific properties by regional characteristics and hierarchical roles.

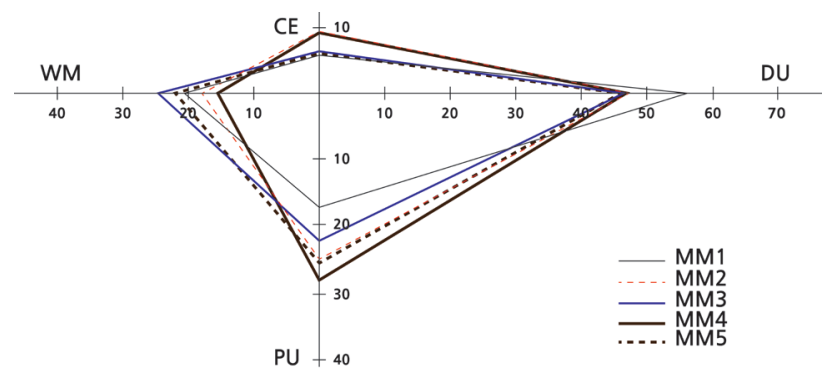

Fig.12. Percentage of Area for the France M. Section

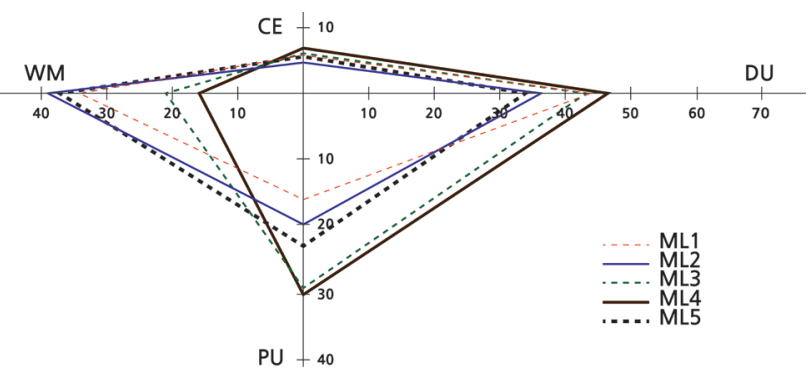

Fig.13. Percentage of Area for the France L. Section

\section{Conclusion}

In this study, the required space composition and current area ratio for public libraries, which changed from a knowledge and information center to a complex cultural community center by a rapidly changing temporal environment around 2000, were investigated and analyzed, leading to the following conclusions.

First, the space composition and area percentage for public libraries developed into a user-centered, open, and complex space due to changes in the information and social environment around 2000. Greater emphasis than before was given to the culture and education sector based on lifelong education and community programs for residents, while resting and public use area formed a higher percentage.

Second, required spaces for public libraries today can be divided into the data usage sector, the culture and education sector, the work management sector, the public use sector, and the miscellaneous sector. The data usage sector is subdivided into general data space, digital data space, and children's data space by information data type and reading type and is composed of open and integrated archive space. The culture and education sector contains a cultural education room, exhibition room, and multipurpose room and also includes a learning room by regional characteristics. The work management sector is subdivided into the office, work supporting room, and stack room for preservation. The public use sector is subdivided into the hall, the hallway, the stairs, and the resting area, consisting of the cafeteria, book café, and resting room. The miscellaneous sector contains an equipment room and underground parking spaces, which were excluded in estimating the net gross floor area of libraries since it varied significantly by regional characteristics. 
Third, required spaces for public libraries were divided into nine types based on size and regional characteristics. Public libraries had reduced data usage sectors and increased public use sectors with an increase in GFA. The L. Section, mostly a central building, had an increased work management sector as GFA increased, with increases in workspace and stack room for preservation. The L. Section had the data usage sector and the public use sector correlatively changed, while M. Section had the management and culture sectors and the public use sector correlatively changed. In contrast, the data usage sector correlated with the culture sector in the S. Section, with no change in the public use sector. The regional characteristics to build public libraries were classified into the megapolis regions (M), small and medium size cities (City), and rural areas (Town) on the basis of the population size and density. The culture and education sector had the highest area percentage in Town. This was because Towns had public libraries that served as spots for lifelong education and local communities due to fewer cultural facilities compared with other regions. City had the area of the data usage and management sector and that of the public use sector correlatively changed. Metropolis had the area of the public use sector and that of the data usage sector correlatively changed in the medium and large sizes.

When type classification was made according to subdivided regional and size criteria for analysis, each type showed a consistent tendency of change in each sector and a different area composition ratio.

Fourth, closed stack rooms connected to the circulation room formed $9 \%$ of the data usage sector in public libraries in small and medium size cities before 2000, compared with the current open shelf system. The percentage of area for digital data in the data usage sector has increased since 2000. The percentage of area for the culture and education sector has doubled, due to the increase in the demand for lifelong education. In contrast, there was no significant change in the area composition ratio for the work management and public use sectors. This increase in the percentage of area for open shelf systems, digital data, and culture and education rooms is the principal change in public libraries. In other words, public libraries giving priority to book preservation and management before 2000 have been diversified since 2000 , leading to their transformation into cultural centers and local community centers for lifelong education in addition to the function of preserving books and reading. The three countries show a $22.5 \%$ higher percentage of area, on average, for the data usage sector, but about a $16 \%$ lower percentage for the public use sector than Korea. In other words, they are identical in that the data usage sector is correlated with the public use sector, but in opposite ways. This is because of the differences in the manner of operating public libraries.
In this study, comparative analysis was made in terms of the current conditions and typical characteristics of required spaces and the area composition ratio to determine the area ratio and characteristic direction for required spaces according to the size and regional characteristics of local public libraries after 2000. However, it was impossible to identify consistent changes and required spaces in detail for each room. An important research objective will be to identify subdivided regional characteristics and investigate the trends of detailed changes. An effective guideline for future research will ultimately be to macroscopically investigate the principal issues of required spaces and area ratios, as in this study, on the rapidly changed library environment around the year 2000 .

\section{References}

1) Dahlgren, A. (1988) Public Library Space Needs: A Planning Outline. Wisconsin: Wisconsin Department of Public Instruction.

2) Lee, K. et al. (1988) An Architectural Planning. Seoul: Munundang.

3) Japanese Architecture Society. (1986) The Casebook on Architectural Planning: Architecture-Culture vol 7. Tokyo: Jimmunsa.

4) Dupuit, J. (1996) Bibliotheques Dans La Cite. Paris: Cite de l'architecture \& du patrimoine.

5) Lushington, N. (2002) Library Design for Users: A 21st Century Guide. USA: Neal-Schuman Publisher.

6) IFLA. (2007) Library Building Guidelines: Developments \& Reflections. Hague: International Federation of Library Associations and Institutions.

7) Korean Biblia Society for Library and Information Science. (2007). A Research on the Actual Condition of Spatial Operation of Libraries and a Study on Standard Models. Seoul: The National Library of Korea.

8) Romero, S. (2008) Library Architecture: Public Library Standards for Catalonia. Spain: COAC(Collegi d'Architectes de Catalunya).

9) Ministry of Culture, Sports and Tourism. (2010) A Manual of Public Library Establishment and Management. Seoul: Ministry of Culture, Sports and Tourism.

10) Ministry of Culture, Sports and Tourism. (2012) A Casebook on Architecture of Public Libraries. Seoul: Ministry of Culture, Sports and Tourism.

11) Korean Library Association. (2013) The Korean Library Standard. Seoul: Ministry of Culture, Sports and Tourism.

12) Lim, H. (2007) A Study on Changes and Characteristics of the Space System of the Public Libraries-focused on the Médiathèque in France. Doctorate thesis, Hongik University, pp.90-91.

13) Lim, H. and Kim, S. (2009) Changes in Spatial Organization in French Public Libraries. Journal of Asian Architecture and Building Engineering, 8 (2), pp.232-330. 